\title{
Profil Berpikir Reflektif Siswa SMP dalam Menyelesaikan Soal PISA Ditinjau dari Kecemasan Matematika
}

\author{
Linda Kartikasari ${ }^{1}$, Ika Kurniasari ${ }^{2}$ \\ ${ }_{1,2}$ Program Studi Pendidikan Matematika, Fakultas Matematika dan Ilmu Pengetahuan Alam, Universitas Negeri Surabaya, \\ Jl. Ketintang, Gayungan, Surabaya, Jawa Timur, Indonesia \\ linda.17030174087@mhs.unesa.ac.id
}

\begin{abstract}
The purpose this study to determine the reflective thinking ability of junior high school students in solving PISA questions based mathematical anxiety levels. The research subjects were grade IX students, which included three students with reflective thinking skills, each of which had low, medium, and high levels of math anxiety. This research is descriptive research with qualitative approach. Data collection was started by giving math anxiety test to class IX students to get one student with low math anxiety level, one student with moderate math anxiety, and one student with high math anxiety, then giving PISA test questions and conducting interviews. The results showed that students with low levels of mathematics anxiety performed all indicators of reflective thinking and four steps to solving the Polya problem, reacting, comparing, and contemplating at the stage of understanding the problem, making plans, implementing plans, and re-examining in solving PISA questions. Students with mathematics anxiety level were doing comparing and contemplating at the stage of making plans, implementing plans, and checking again. Meanwhile, students with high level of math anxiety did comparing and contemplating at the stage of planning and implementing plans.
\end{abstract}

Keywords: reflective thinking, PISA, mathematics anxiety

\section{Abstrak}

Tujuan penelitian ini yaitu untuk mengetahui kemampuan berpikir reflektif siswa SMP dalam menyelesaikan soal PISA berdasarkan tingkat kecemasan matematika. Subjek penelitian yaitu siswa SMP kelas IX yang meliputi tiga siswa dengan kemampuan berpikir reflektif yang masing-masing mempunyai tingkat kecemasan matematika rendah, sedang, dan tinggi. Penelitian ini merupakan penelitian deskriptif dengan pendekatan kualitatif. Pengambilan data dimulai dengan memberikan tes kecemasan matematika kepada siswa kelas IX untuk mendapatkan satu siswa dengan tingkat kecemasan matematika rendah, satu siswa dengan kecemasan matematika sedang, dan satu siswa dengan kecemasan matematika tinggi, kemudian memberikan tes soal PISA matematika dan melakukan wawancara. Hasil penelitian menunjukkan bahwa siswa dengan tingkat kecemasan matematika rendah melakukan semua indikator berpikir reflektif serta empat langkah menyelesaikan masalah Polya yaitu reacting, comparing, dan contemplating pada tahap memahami masalah, menyusun rencana, melaksanakan rencana, dan memeriksa kembali dalam menyelesaikan soal PISA. Siswa dengan tingkat kecemasan matematika sedang melakukan comparing dan contemplating pada tahap menyusun rencana, melaksanakan rencana, dan memeriksa kembali. Sedangkan, siswa dengan tingkat kecemasan matematika tinggi melakukan comparing dan contemplating pada tahap menyusun rencana dan melaksanakan rencana.

Kata kunci: Berpikir Reflektif, PISA, Kecemasan Matematika

Copyright (c) 2021 Linda Kartikasari, Ika Kurniasari

$\triangle$ Corresponding author: Linda Kartikasari

Email Address: linda.17030174087@mhs.unesa.ac.id (J1. Ketintang, Gayungan, Surabaya, Jawa Timur)

Received 25 July 2021, Accepted 23 August 2021, Published 06 September 2021

\section{PENDAHULUAN}

Pendidikan adalah usaha manusia yang digunakan dalam membina kepribadian berdasarkan dengan nilai-nilai yang berlaku baik di masyarakat maupun kebudayaan. Matematika dalam dunia pendidikan menjadi salah satu ilmu yang mendasari daya pikir manusia, perkembangan teknologi modern, serta ilmu-ilmu lain (Kusumaningrum \& Saefudin, 2012). Matematika termasuk salah satu pelajaran wajib pada semua jenjang pendidikan di sekolah, mulai dari TK, SD, SMP, SMA bahkan 
Profil Berpikir Reflektif Siswa SMP dalam Menyelesaikan Soal PISA Ditinjau dari Kecemasan Matematika, Linda Kartikasari, Ika Kurniasar

sampai Perguruan Tinggi, sehingga matematika mendapat perhatian besar baik dari siswa, guru, orangtua, dan pemerintah. Tujuan yang harus diraih pada pembelajaran matematika yaitu meningkatkan kemampuan siswa untuk berpikir tingkat tinggi (higher order thinking). Salah satu kemampuan berpikir siswa yang termasuk ke dalam kemampuan berpikir tingkat tinggi (higher order thinking) yaitu kemampuan berpikir reflektif. Hal tersebut sesuai dengan pernyataan Suharna (2018), "Higher order thinking skills include critical, logical, reflective thinking, metacognitive, and creative thinking". Artinya berpikir tingkat tinggi termasuk berpikir kritis, berpikir logis, berpikir reflektif, metakognitif, dan berpikir kreatif. Berpikir reflektif dapat diterapkan dalam pembelajaran matematika (Odafe, 2008) dan berpikir reflektif merupakan unsur yang paling penting untuk belajar secara efektif (Walle, 2008). Pendapat para ahli ini bisa menjadi dasar mengenai pentingnya mengetahui berpikir reflektif siswa.

Menurut Rhaudyatun (2017) berpikir reflektif adalah kemampuan berpikir siswa dalam menghubungkan pengetahuan sebelumnya dalam menganalisis, menilai, membuat keputusan, mengevaluasi masalah untuk memperoleh kesimpulan. Berpikir reflektif merupakan aktivitas mental seseorang dalam mengidentifikasi dan menyelesaikan masalah dengan menggunakan pengetahuan serta pengalaman yang berkaitan dengan masalah yang dihadapi serta melakukan komponen berpikir reflektif yaitu reacting, elaborating, dan contemplating (Rasyid et al., 2017). Sejalan dengan hal itu, Ariestyan (2016) menyebutkan tahapan berpikir reflektif meliputi reacting (berpikir reflektif untuk aksi), yaitu bereaksi dan menggunakan pengetahuan yang didapatkan sebagai pengalaman belajar terhadap suatu peristiwa untuk mengidentifikasi masalah, comparing/elaborating (berpikir reflektif untuk evaluasi), siswa mengaitkan pengetahuan yang telah dipelajari dengan masalah yang sedang dihadapi dalam mengidentifikasi masalah, contemplating (berpikir reflektif untuk inkuiri kritis) yaitu menguji solusi dalam memecahkan masalah dan menggunakannya untuk menghasilkan simpulan. Pada tahap berpikir reflektif reacting menurut Lutfiananda et al. (2016) siswa menyebutkan apa yang diketahui dan yang ditanyakan serta menyebutkan hubungan antara hal yang diketahui dan yang ditanya. Pada tahap berpikir reflektif comparing, siswa menghubungkan pengetahuan yang diperoleh dengan pengetahuan yang telah dimiliki dalam menyelesaikan masalah serta menjelaskan persamaan dan perbedaan dengan masalah sebelumnya(Ariestyan et al., 2016). Sedangkan, pada tahap contemplating menurut Suharna (2018) siswa menyadari jika ada kesalahan ketika menyelesaikan masalah dan dapat memperbaikinya.

Kemampuan berpikir reflektif perlu dimiliki siswa karena mendorong proses berpikir siswa dalam pemecahan masalah sehinggacdapat mengeksplorasi masalah dengan mengidentifikasi konsep matematika yang terlibat, menggunakan berbagai strategi alternatif, membangun ide-ide, menarik kesimpulan, dan memeriksa ulang solusi (Puspitasari, 2019). Siswa juga memerlukan kemampuan berpikir reflektif dalam memecahkan masalah matematika sebagai kecakapan siswa dalam mengingat, mengidentifikasi masalah, dan mempertimbangkan informasi untuk mengaitkan permasalahan yang diperoleh (Suhaji et al., 2020). Hal tersebut menunjukkan bahwa pentingnya berpikir reflektif dalam pembelajaran matematika, terutama dalam memecahkan masalah matematika. Berpikir reflektif mengutamakan pada kemampuan seseorang ketika menyelesaikan masalah dan menghubungkan antara 
pengetahuan yang telah dimiliki dan pengetahuan yang sedang dipelajari siswa ketika menganalisis permasalahan guna memperoleh penyelesaian terbaik dari masalah yang diberikan (Fuady, 2017). Berpikir reflektif juga memiliki kaitan erat dengan kemampuan mempertimbangkan sesuatu yang berhubungan dengan kehidupan nyata serta membantu siswa untuk meningkatkan kemampuan berpikir tingkat tinggi. Berdasarkan hal tersebut, apabila dihubungkan dengan PISA berdasarkan OECD (2016), soal PISA matematika memiliki kaitan yang erat dengan kemampuan menafsirkan hal-hal matematis pada beragam konteks yang berbeda serta membantu siswa dalam memahami peranan matematika di kehidupan nyata untuk membuat penilaian serta keputusan. Berdasarkan hal tersebut, berpikir reflektif diperlukan siswa ketika menyelesaikan masalah matematika yang berkaitan dengan standar soal PISA.

PISA (Programme for International Student Assesment) adalah studi internasional yang diadakan oleh OECD bertujuan untuk menilai sejauh mana siswa yang mendekati akhir wajib belajar atau siswa yang berumur 15 tahun untuk mendapatkan pengetahuan dan keterampilan ketika berperan serta dalam masyarakat modern (Putra \& Vebrian, 2020). Penilaian PISA matematika melaporkan hasilnya berdasarkan tiga kategori proses yang meliputi merumuskan situasi secara matematis, menerapkan konsep, fakta, prosedur dan penalaran matematika, serta menafsirkan, menerapkan dan mengevaluasi hasil matematika (OECD, 2013). Berdasarkan framework PISA 2018 konten literasi matematika terbagi ke dalam 4 konten yakni, bilangan (quantity), probabilitas/ketidakpastian dan data (uncertainty and data), perubahan dan hubungan (change and relationship), ruang dan bentuk (space and shape) (OECD, 2018). Dalam penilaian PISA sesuai framework tahun 2019 kategori konteks (contexts) literasi matematika ada 4 konteks yaitu, pribadi (personal), pekerjaan (occupational), sosial/umum (societal), dan keilmuaan/ilmiah (scientific) (OECD, 2019). Pada penelitian ini, peneliti menggunakan soal PISA level 4 yang merupakan soal HOTS (Highe Order Thinking Skills) karena berpikir reflektif diperlukan oleh siswa ketika menyelesaikan soal PISA level 4 yang dalam penyelesaiannya membutuhkan kemampuan berpikir tingkat tinggi yaitu kemampuan berpikir reflektif siswa (Suharna, 2018). Peneliti juga memilih siswa SMP kelas IX yang berumur 15 sebagai subjek penelitian karena studi PISA diselenggarakan untuk siswa yang berumur 15 tahun.

Menurut Ruseffendi (2006), matematika sering dipandang sebagai ilmu yang ruwet dan sulit karena siswa tidak mampu memahami pada bagian yang sederhana sekalipun ketika belajar matematika. Faktor penyebab matematika dipandang sebagai pelajaran yang sulit karena berdasarkan karakteristik materi matematika yang bersifat abstrak, logis, sistematis, dan banyak lambang-lambang serta rumus yang memusingkan siswa. Faktor kesulitan siswa ketika menyelesaikan masalah matematika salah satunya yaitu adanya perasaan cemas pada siswa yang muncul karena adanya pengalaman siswa ketika belajar matematika. Keadaan siswa ketika merasa cemas atau tegang saat belajar matematika disebut dengan istilah kecemasan matematika (Machromah et al., 2015). Kecemasan matematika merupakan perasaan tegang, panik, dan gangguan mental yang muncul pada seseorang ketika menyelesaikan masalah matematika serta menjadi salah satu aspek afektif yang dapat mempengaruhi pembelajaran matematika (Supriatna \& Zulkarnaen, 2019). Menurut Al Mutawah (2015) kecemasan matematika 
Profil Berpikir Reflektif Siswa SMP dalam Menyelesaikan Soal PISA Ditinjau dari Kecemasan Matematika, Linda Kartikasari, Ika Kurniasar

adalah perasaan cemas atau tegang yang mengganggu bagi seseorang ketika menyelesaikan masalah matematika. Menurut Mutodi \& Ngirande (2014) mengkategorikan kecemasan matematika menjadi empat kategori yaitu tidak memiliki kecemasan matematika, kecemasan matematika rendah, kecemasan matematika sedang, dan kecemasan matematika tinggi. Pada penelitian ini menggunakan tingkatan kecemasan matematika yang meliputi kecemasan matematika rendah, kecemasan matematika sedang, dan kecemasan matematika tinggi serta menggunakan acuan skala kecemasan Hamilton Anxiety Rating Scale (HARS) (Nursalam, 2013) dengan kriteria subjek sebagai berikut.

Tabel 1. Kriteria Subjek Tes Kecemasan Matematika

\begin{tabular}{|c|c|c|}
\hline \multicolumn{3}{|c|}{ Kriteria Subjek dalam Tes Kecemasan Matematika } \\
\hline Kecemasan rendah & Kecemasan rendah & Kecemasan rendah \\
\hline $0<$ skor angket $\leq 20$ & $21 \leq$ skor angket $\leq 27$ & $28 \leq$ skor angket $\leq 100$ \\
\hline
\end{tabular}

Kecemasan matematika yang dirasakan siswa dapat mempengaruhi suasana hati dan emosi siswa. Oleh karena itu, kecemasan matematika yang dialami siswa dapat mengganggu proses berpikir, lebih khususnya proses berpikir reflektif siswa dalam pembelajaran maupun ketika menyelesaikan soal PISA matematika.

Penelitian yang memiliki relevansi dengan penelitian ini adalah penelitian yang dilakukan oleh Jannah (2018) berjudul Profil Berpikir Reflektif Siswa SMA dalam Memecahkan Masalah Matematika ditinjau dari Kemampuan Matematika, hasil penelitian menunjukkan bahwa siswa dengan kemampuan matematika tinggi mengalami berpikir reflektif sesuai indikator berpikir reflektif, reacting, comparing, contemplating, sedangkan siswa dengan kemampuan matematika sedang dan rendah tidak mengalami indikator berpikir reflektif. Selanjutnya penelitian oleh Juhaevah (2017) berjudul Profil Kemampuan Berpikir Reflektif Siswa SMP dalam Memecahkan Masalah Matematika Standar PISA ditinjau dari Perbedaan Gender, hasil penelitian menunjukkan siswa laki-laki melakukan comparing pada saat menyusun rencana pada masalah PISA quantity dan melakasanakan rencana pada masalah PISA change and relationship, sedangkan siswa perempuan melakukan semua komponen berpikir reflektif pada masalah PISA change and relationship. Penelitian terakhir yang dilakukan oleh Melisa (2019) dengan judul Pengaruh Kecemasan Matematika terhadap Kemampuan Pemecahan Masalah Matematis berdasarkan Gender, hasil penelitian menunjukkan bahwa terdapat pengaruh kecemasan matematika dan gender terhadap kemampuan pemecahan masalah matematis berdasarkan gender.

Studi-studi tersebut memaparkan hasil dari berpikir reflektif siswa dalam menyelesaikan masalah matematika dengan tinjauan yang berbeda-beda. Sehingga dalam hal ini, berpikir reflektif siswa dalam menyelesaikan soal PISA ditinjau dari kecemasan matematika menjadi topik yang masih sedikit dalam penelitian, sedangkan telah dijabarkan pada penjelasan di atas bahwa berpikir reflektif dibutuhkan siswa dalam membantu mengkonstruk pengetahuan baru dari pengetahuan sebelumnya serta didukung dengan kebutuhan siswa dalam menyelesaikan permasalahan matematika berstandar soal PISA, sejalan dengan hal tersebut penelitian tentang berpikir reflektif yang dilakukan Jannah (2018) yaitu siswa 
dengan kemampuan matematika tinggi mengalami berpikir reflektif reacting, comparing, contemplating, sedangkan siswa dengan kemampuan matematika sedang dan rendah tidak mengalami berpikir reflektif, berdasarkan hasil penelitian tersebut peneliti tertarik untuk melakukan tinjauan penelitian lain yang relevan dengan penelitian tersebut yaitu berpikir reflektif siswa berdasarkan kecemasan matematika, dimana kecemasan matematika siswa dipilih dalam penelitian ini karena peneliti memperhatikan siswa di sekolah yang sering merasa cemas atau tegang ketika bertemu dengan pelajaran matematika sehingga mengakibatkan siswa belum bisa maksimal dalam pembelajaran matematika atau dalam menyelesaikan soal PISA matematika. Berdasarkan seluruh uraian di atas, peneliti melakukan penelitian yang bertujuan untuk mendeskripsikan berpikir reflektif siswa SMP yang memiliki tingkat kecemasan matematika rendah, sedang, dan tinggi dalam menyelesaikan soal PISA.

\section{METODE}

Jenis penelitian ini yaitu penelitian deskriptif dengan pendekatan kualitatif. Subjek penelitian terdiri dari tiga siswa kelas IX SMP Negeri 2 Bancar, Tuban. Pemilihan subjek didapatkan dengan memberikan tes kecemasan matematika kepada siswa kelas IX, kemudian berdasarkan skor nilai dan pengkategorian kecemasan matematika berdasarkan acuan pada Tabel 1 yaitu ada 7 siswa dengan kategori kecemasan matematika rendah, 3 siswa dengan kecemasan matematika sedang, dan ada 13 siswa dengan kecemasan matematika tinggi, selanjutnya subjek penelitian dipilih masing-masing satu siswa dari setiap tingkat kecemasan matematika yang harus bisa menyampaikan secara lisan dan sistematis. Setelah itu, ketiga subjek diberikan tes soal PISA dan melakukan wawancara. Instrumen utama dalam penelitian ini adalah peneliti sendiri karena hanya peneliti yang dapat menguasai kondisi di lapangan ketika dilakukannya proses penelitian dan instrumen pendukung yaitu tes kecemasan matematika, tes soal PISA, dan pedoman wawancara. Pada angket kecemasan matematika terdapat 14 pernyataan dengan bentuk pertanyaan yang bertipe pilihan dan meminta siswa untuk memilih salah satu jawaban yang sesuai dari beberapa jawaban yang tersedia. Instrumen tes soal PISA berbentuk tes tulis yang materinya sudah didapat semua oleh siswa kelas IX dan dikerjakan secara individu.

Teknik analisis data diawali dengan menganalisis data hasil tes kecemasan matematika dilanjut dengan menganalisis data hasil tes soal PISA, dan yang terakhir adalah analisis data hasil wawancara. Karakteristik soal PISA matematika yang digunakan yaitu soal HOTS (Highe Order Thinking Skills). Tes soal PISA yang digunakan berjumlah 2 soal. Soal PISA pertama berkaitan dengan pokok pelajaran geometri dan konsep sudut, proses penyelesaiannya dengan cara menafsirkan (interpret), soal level 4 dengan konteks umum (societal) serta menggunakan konten ruang dan bentuk (space and shape), dan soal PISA kedua berkaitan dengan pokok bahasan statistika, proses penyelesaiannya dengan cara menerapkan (employ), soal level 4 dengan konteks umum (societal) dan menggunakan konten ketidakpastian dan data (uncertainty and data). Hasil tes soal PISA dianalisis sesuai indikator berpikir reflektif dalam menyelesaikan soal PISA dan melalui 4 tahapan pemecahan masalah Polya (Roebyanto \& Harmini, 2017). Pada penelitian ini menggunakan indikator berpikir reflektif sebagai berikut: 
Profil Berpikir Reflektif Siswa SMP dalam Menyelesaikan Soal PISA Ditinjau dari Kecemasan Matematika, Linda Kartikasari, Ika Kurniasar

Tabel 2. Indikator Berpikir Reflektif dalam Menyelesaikan Soal PISA Matematika

\begin{tabular}{|c|c|c|}
\hline $\begin{array}{l}\text { Komponen Berpikir } \\
\text { Reflektif }\end{array}$ & $\begin{array}{l}\text { Tahapan Pemecahan } \\
\text { Masalah }\end{array}$ & Indikator \\
\hline \multirow[t]{3}{*}{ Reacting } & \multirow[t]{3}{*}{ Memahami Masalah } & $\begin{array}{l}\text { Menuliskan hal yang diketahui } \\
\text { berdasarkan informasi dalam soal PISA }\end{array}$ \\
\hline & & $\begin{array}{l}\text { Menuliskan hal yang ditanya sesuai } \\
\text { dengan informasi pada soal PISA }\end{array}$ \\
\hline & & $\begin{array}{l}\text { Menjelaskan keterkaitan antara hal yang } \\
\text { diketahui dengan hal yang ditanya }\end{array}$ \\
\hline \multirow[t]{3}{*}{ Comparing/Elaborating } & \multirow[t]{3}{*}{ Menyusun Rencana } & $\begin{array}{l}\text { Menyusun rencana penyelesaian } \\
\text { berdasarkan pengalaman atau konsep } \\
\text { matematika yang telah dimiliki oleh siswa } \\
\text { ketika menyelesaikan soal PISA }\end{array}$ \\
\hline & & $\begin{array}{l}\text { Menganalisis hubungan yang meliputi } \\
\text { persamaan dan perbedaan antara tes soal } \\
\text { PISA yang dikerjakan dengan soal yang } \\
\text { sebelumnya pernah dijumpai oleh siswa }\end{array}$ \\
\hline & & $\begin{array}{l}\text { Menganalisis metode/strategi yang efektif } \\
\text { dalam menyelesaikan soal PISA }\end{array}$ \\
\hline \multirow[t]{4}{*}{ Contemplating } & \multirow[t]{2}{*}{ Melaksanakan Rencana } & $\begin{array}{l}\text { Menyelesaikan soal PISA berdasarkan } \\
\text { konsep matematika yang dimiliki siswa }\end{array}$ \\
\hline & & Membuat kesimpulan dengan tepat \\
\hline & \multirow[t]{2}{*}{ Memeriksa Kembali } & $\begin{array}{l}\text { Memeriksa ulang langkah penyelesaian } \\
\text { yang telah dibuat }\end{array}$ \\
\hline & & $\begin{array}{l}\text { Menyadari kesalahan dan dapat } \\
\text { memperbaiki jika terdapat kesalahan dari } \\
\text { penyelesaian yang telah dibuat. }\end{array}$ \\
\hline
\end{tabular}

Instrumen penelitian yang digunakan telah melalui proses konsultasi dengan dosen pembimbing. Terakhir pada analisis data hasil wawancara menggunakan acuan analisis data kualitatif yaitu reduksi data, penyajian data, dan penarikan kesimpulan (Miles et al., 2014).

\section{HASIL DAN DISKUSI}

Hasil penelitian menunjukkan bahwa subjek menyelesaikan soal PISA melalui tiga tahapan berpikir reflektif reacting, comparing/elaborating, dan contemplating (Ariestyan et al., 2016) serta 4 langkah penyelesaian masalah Polya yaitu, memahami masalah, membuat rencana, melaksanakan rencana, dan memeriksa kembali (Roebyanto \& Harmini, 2017). Subjek penelitian terdiri dari satu siswa dengan kategori kecemasan matematika rendah (SR) yang mendapat skor di antara 0 sampai dengan 21 , satu siswa dengan kecemasan matematika sedang (SS) yang mendapat skor di antara 20 sampai dengan 28, dan satu siswa dengan kecemasan matematika tinggi (ST) yang mendapat skor di antara 27 sampai dengan 101. Setelah itu subjek diberikan tes soal PISA untuk dikerjakan secara individu dan yang terakhir adalah wawancara. Hasil dari tes kecemasan matematika siswa sebagai berikut. 
Tabel 3. Kategori Tes Kecemasan Matematika Siswa

\begin{tabular}{|c|c|c|c|}
\hline Nama & Nilai Tes Kecemasan Matematika & Kategori & Kode \\
\hline ANS & 5 & Rendah & SR \\
\hline STH & 23 & Sedang & SS \\
\hline AND & 30 & Tinggi & ST \\
\hline
\end{tabular}

Hasil analisis dan pembahasan pada profil berpikir reflektif siswa SMP ketika menyelesaikan soal PISA matematika ditinjau dari kecemasan matematika sebagai berikut:

1. Berpikir reflektif siswa SMP ketika menyelesaikan soal PISA matematika pada tingkat kecemasan matematika rendah

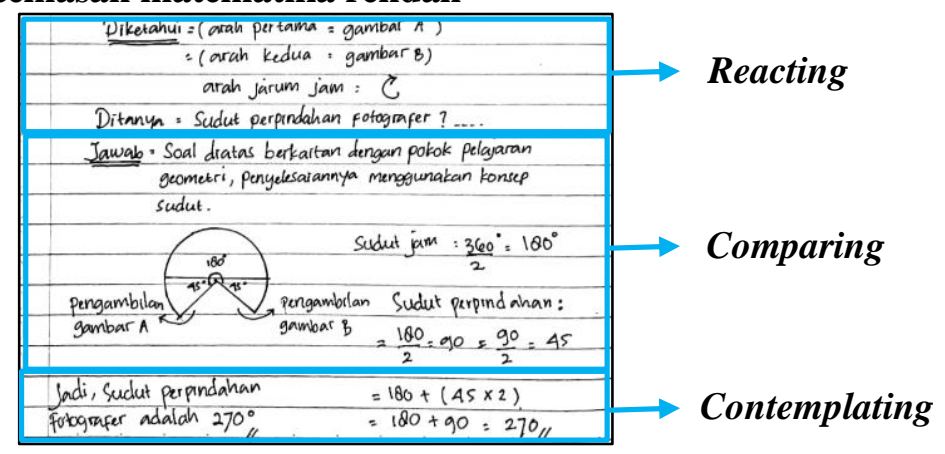

Gambar 1. Hasil Tes Tulis Nomor 1 SR

Hasil tes soal PISA di atas menunjukkan bahwa pada tahap reacting ketika memahami masalah, SR menuliskan hal yang diketahui dan yang ditanya sesuai dengan pendapat Lutfiananda et al. (2016), siswa menyebutkan apa yang diketahui dan yang ditanya serta hubungan antara hal yang diketahui dan yang ditanya pada tahap reacting. Wawancara SR pada tahap reacting sebagai berikut.

P $: \quad \begin{aligned} & \text { Menurutmu, apakah informasi yang diberikan oleh soal PISA nomor } 1 \text { sudah cukup untuk } \\ & \text { menyelesaikan soal tersebut? Kemudian jelaskan juga alasannya? }\end{aligned}$
SR : $\quad \begin{aligned} & \text { Sudah cukup bu. Karena setelah saya hitung ketemu jawabannya dan ada gambar sebagai } \\ & \text { bantuan juga bu. }\end{aligned}$

Pada tahap comparing, SR menyusun rencana sesuai konsep matematika yang telah dimiliki, menyatakan pernah menjumpai soal yang serupa dengan menjelaskan perbedaan dan persamaannya serta menganalisis metode/strategi yang efektif, sesuai pernyataan Ariestyan et al. (2016), siswa menghubungkan pengetahuan yang diperoleh dengan pengetahuan yang dimiliki serta menjelaskan persamaan dan perbedaannya. Pada tahap comparing dilakukan wawancara sebagai berikut.

$P \quad: \quad$ Apa langkah awal yang kamu lakukan untuk menyelesaikan soal PISA nomor 1? Lalu metode/strategi apa yang kamu anggap efektif dalam menyelesaikan soal PISA tersebut?

SR : $\quad$ Saya mempelajari kembali mengenai konsep sudut di BKS (Buku Kerja Siswa) kelas 9 semester 1 bu, ada pembahasan tentang sudut lingkaran. Menurut saya metode/strategi yang tepat adalah menggunakan aturan sudut pada lingkaran, pada soal tersebut saya 
Profil Berpikir Reflektif Siswa SMP dalam Menyelesaikan Soal PISA Ditinjau dari Kecemasan Matematika, Linda

menggambar lingkaran lalu besar perpindahannya saya bagi sudut pada lingkaran tersebut menjadi 3 yaitu $45^{\circ}, 180^{\circ}$, dan $45^{\circ}$ bu.

$P \quad$ : Pernahkah kamu menjumpai soal yang serupa dengan soal PISA tersebut sebelumnya? Jika pernah, coba jelaskan perbedaan dan persamaannya?

SR : Kalau yang sama belum pernah bu, tetapi kalau soal tentang sudut sudah pernah. Persamaannya yaitu sama-sama tentang menghitung besar sudut, sedangkan perbedaannya menurut saya soal PISA tersebut lebih sulit daripada soal yang pernah saya jumpai, karena pada soal tidak ada gambar sudut bantuan tetapi cuma ada gambar bangunan, jadi harus mencari dan menghitung sendiri sudut perpindahannya.

Pada tahap berpikir reflektif contemplating ketika melaksanakan rencana dan memeriksa kembali pada subjek SR dilakukan wawancara sebagai berikut.

$P$ : Selanjutnya, dengan cara apa kamu menyelesaikan soal PISA nomor 1? Jelaskan pula kesimpulan yang kamu peroleh setelah menyelesaikan soal PISA tersebut?

SR : Soal tersebut berkaitan dengan pelajaran geometri, penyelesaiannya menggunakan konsep sudut. Saya menyelesaikan soal tersebut dengan cara menghitung sudut perpindahan yaitu mencari besar sudut dari gambar a dan $b$ dengan bantuan sudut lingkaran yang sudah saya buat, yaitu $45^{\circ}+180^{\circ}+45^{\circ}=270^{\circ}$. Kesimpulannya besar sudut perpindahan fotografer dari gambar a ke gambar b yaitu $270^{\circ} \mathrm{bu}$.

$P$ : Apakah kamu telah memeriksa kembali penyelesaian yang kamu dapatkan? Lalu bagaimana kamu memeriksa kembali penyelesaianmu?

SR : $\quad$ Sudah bu. Dengan cara menghitung kembali 3 sudut yang terbentuk dari gambar yang sudah saya buat. Jadi besar sudut perpindahannya adalah $45^{\circ}+180^{\circ}+45^{\circ}=270^{\circ}$ bu .

Subjek SR menggunakan konsep matematika yang sudah dimiliki serta membuat kesimpulan dengan tepat pada tahap contemplating, sesuai pernyataan Mardiyah (2019), siswa melakukan tranformasi terhadap konsep yang sudah dimiliki untuk membentuk konsep baru dalam menyelesaikan masalah. Subjek SR memeriksa kembali penyelesaian yang telah dibuat, menyadari dan dapat memperbaiki apabila ada kesalahan, sehingga SR telah memenuhi tahap contemplating.

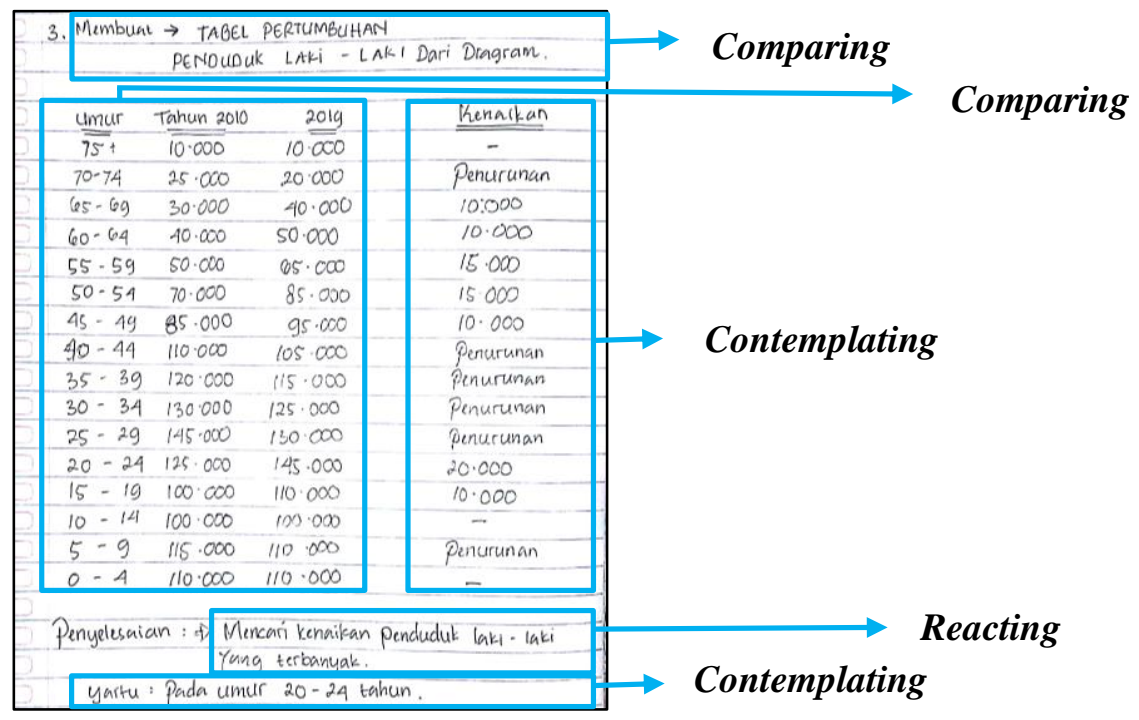

Gambar 2. Hasil Tes Tulis Nomor 2 SR 
Hasil tes soal PISA di atas menunjukkan pada tahap reacting SR tidak menuliskan hal yang diketahui tetapi menuliskan hal yang ditanya serta menjelaskan hubungan antara hal yang diketahui dan yang ditanya, sesuai pendapat Wiryanto (2014), siswa menunjukkan hubungan yang mendasari dalam menghadapi suatu masalah. Pada tahap reacting dilakukan wawancara sebagai berikut.
$P \quad$ : Apakah informasi yang diberikan oleh soal sudah cukup untuk menyelesaikan soal PISA? Kemudian jelaskan juga alasannya?
SR : Iya, sudah bu. Karena dari gambar diagram penduduk tahun 2010 dan 2019 yang diketahui dalam soal saya dapat menjawab soal tersebut bu.

Pada tahap comparing, SR menyusun langkah awal berdasarkan konsep matematika yang telah dimiliki, menyatakan bahwa pernah menjumpai soal yang serupa dengan menganalisis perbedaan dan persamaannya serta dapat menganalisis metode/strategi yang efektif, sesuai dengan pernyataan Juhaevah (2017), pada tahap comparing siswa dapat memberikan strategi alternatif dalam menyelesaikan masalah. Pada tahap comparing dilakukan wawancara sebagai berikut.

$P$ : Apa langkah awal yang kamu lakukan untuk menyelesaikan soal PISA tersebut? Kemudian metode/strategi apa yang efektif dalam menyelesaikan soal PISA tersebut?

$S R$ : Langkah awal yang saya lakukan yaitu saya membuat data kisaran pertumbuhan jumlah kenaikan penduduk terlebih dahulu bu. Menurut saya metode/strategi apa yang efektif yaitu menganalisis terlebih dahulu pertumbuhan penduduk laki-laki pada tahun 2010 dan tahun 2019, selanjutnya menentukan kenaikan yang paling tinggi bu

$P \quad$ : Apakah kamu sudah pernah menjumpai soal yang serupa dengan soal PISA tersebut? Kemudian coba jelaskan perbedaan dan persamaan antara soal yang pernah kamu jumpai dengan soal PISA yang sudah kamu kerjakan?

SR : Iya, pernah bu. Persamaannya yaitu sama-sama menggunakan diagram. Perbedaanya adalah jika pada soal nomor 2 menggunakan 2 diagram sekaligus, sedangkan pada soal yang pernah saya temui hanya menggunakan 1 diagram bu

Pada tahap berpikir reflektif contemplating ketika melaksanakan rencana dan memeriksa kembali pada subjek SR dilakukan wawancara sebagai berikut.

$P \quad: \quad$ Selanjutnya, dengan cara apa kamu menyelesaikan soal PISA nomor 2 tersebut? Jelaskan pula kesimpulan yang kamu peroleh setelah menyelesaikan soal PISA tersebut?

SR : Dengan cara membuat data pertumbuhan jumlah penduduk pada tahun 2010 dan tahun 2019 pada setiap umur, serta menentukan kenaikan yang paling signifikan bu. Kesimpulan yang saya dapat yaitu jumlah penduduk laki-laki yang mengalami kenaikan paling tinggi adalah pada umur 20-24 tahun dengan kenaikan sebanyak 20.000 jiwa bu

$P$ : Apakah kamu sudah memeriksa kembali penyelesaian yang telah kamu dapatkan? Dan bagaimana kaтu memeriksa kembali penyelesaianmu?

SR : Iya, sudah bu. Saya menghitung kembali data kisaran jumlah penduduk pada tahun 2010 dan tahun 2019 pada setiap umur dan data kenaikan dari pertumbuhan penduduk serta mengamati lagi hasil akhir yang saya peroleh yaitu jumlah penduduk laki-laki yang mengalami kenaikan paling tinggi adalah pada umur 20-24 tahun bu 
Profil Berpikir Reflektif Siswa SMP dalam Menyelesaikan Soal PISA Ditinjau dari Kecemasan Matematika, Linda Kartikasari, Ika Kurniasar

Pada tahap contemplating, SR menyelesaikan soal PISA menggunakan konsep matematika yang sudah dimiliki serta membuat kesimpulan dengan tepat, memeriksa ulang penyelesaian yang telah dibuat serta menyadari dan dapat memperbaiki apabila ada kesalahan, hal ini sesuai dengan pendapat Juhaevah (2017) bahwa pada tahap contemplating siswa memeriksa seluruh tahapan penyelesaian masalah dari awal hingga akhir serta memastikan bahwa penyelesaian yang diperoleh telah menjawab pertanyaan pada soal, sehingga SR telah memenuhi tahap contemplating.

2. Berpikir reflektif siswa SMP dalam menyelesaikan soal PISA matematika pada tingkat kecemasan matematika sedang

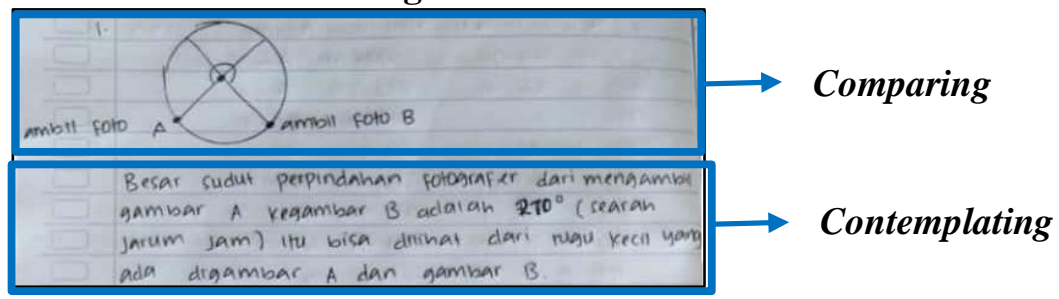

Gambar 3. Hasil Tes Tulis Nomor 1 SS

Berdasarkan tes soal PISA di atas, pada tahap reacting ketika memahami masalah, SS tidak menuliskan hal yang diketahui dan yang ditanya serta tidak menyatakan hubungan antara hal yang diketahui dan yang ditanya, sehingga SS tidak melakukan tahap reacting karena sesuai dengan yang dikemukakan oleh Lutfiananda et al. (2016) bahwa pada tahap reacting, siswa akan menyebutkan apa saja yang diketahui dan yang ditanyakan serta menyebutkan hubungan antara hal yang diketahui dan yang ditanya. Pada tahap reacting dilakukan wawancara sebagai berikut.

$P \quad: \quad$ Bisa kamu jelaskan mengenai hal yang diketahui dan yang ditanyakan dalam soal PISA tersebut? Mengapa kamu tidak menuliskannya pada lembar jawaban?

SS : $\quad$ Yang ditanya adalah besar sudut perpindahan, sedangkan yang diketahui adalah gambar a dan gambar b yang diambil fotografer. Saya lupa tidak menuliskannya karena sudah ada pada soal, jadi saya langsung menulis jawabannya bu

$P \quad: \quad$ Apakah informasi yang diberikan pada soal sudah cukup untuk menyelesaikan soal PISA?

SS : $\quad$ Iya, sudah bu, tapi saya sebenarnya masih bingung karena soal seperti itu baru pertama kali saya temui, dan menurut saya agak sulit daripada soal tentang sudut yang pernah saya temui, tapi saya sudah berusaha untuk menjawabnya bu.

Pada tahap comparing, SS menyusun rencana berdasarkan konsep matematika yang telah dimiliki, mengklarifikasi belum pernah menghadapi soal yang serupa, dan dapat menganalisis metode/strategi yang efektif, sesuai pendapat Juhaevah (2017), siswa memberikan strategi alternatif dalam menyelesaikan masalah. Pada tahap comparing SS dilakukan wawancara sebagai berikut.

$P \quad: \quad$ Apa langkah awal yang kamu lakukan ketika menyelesaikan soal PISA tersebut? Lalu apakah kamu pernah menjumpai soal yang serupa dengan soal PISA tersebut?

SS : $\quad$ Saya membaca dan memahami soal, kemudian menentukan yang diketahui dan ditanya lalu menyelesaikannya dengan cara mencari sudut perpindahannya bu. Saya belum pernah menjumpai soal seperti itu bu, kalau tentang besar sudut sudah pernah, tapi tidak 
sama, biasanya pada soal sudah ada besar salah satu sudut dan di minta mencari sudut yang lainnya, kala soal yang saya kerjakan tadi tidak seperti itu bu, cuma ada gambar

$P \quad: \quad$ Metode/strategi apa yang kamu anggap efektif dalam menyelesaikan soal tersebut?

SS: $\quad$ Saya menggunakan aturan sudut yang pernah saya pelajari sebelumnya dengan menggambar lingkaran kemudian membagi lingkaran menjadi 4 bagian dengan titik tengahnya saya umpamakan sebagai gambar tugunya bu.

Pada tahap berpikir reflektif contemplating ketika melaksanakan rencana dan memeriksa kembali pada subjek SR dilakukan wawancara sebagai berikut.

$P$ : Dengan menggunakan cara apa kamu menyelesaikan soal PISA tersebut? Kemudian jelaskan kesimpulan yang kamu peroleh setelah menyelesaikan soal PISA nomor 1?

SS : Dengan cara mencari besar sudut dari gambar a dan b searah jarum jam dengan membuat lingkaran dan membagi lingkaran tersebut menjadi 4 bagian sama besar, dimana setelah saya gambar lingkaran tersebut dari titik pengambilan gambar a sampai $b$ didapatkan besar sudut $90^{\circ}+90^{\circ}+90^{\circ}=270^{\circ}$ bu. Kesimpulannya besar sudut perpindahan dari gambar a ke gambar b yaitu $90^{\circ}+90^{\circ}+90^{\circ}=270^{\circ}$ bu

$P$ : Apakah kamu sudah memeriksa kembali penyelesaian yang telah kamu dapatkan? Kemudian bagaimana kamu memeriksa kembali penyelesaianmu?

SS : $\quad$ Sudah bu. Dengan cara melihat kembali gambar lingkaran yang sudah saya buat dan kemudian menghitung sudut yang terbentuk dari gambar a ke gambar b dan saya dapatkan besar sudut perpindahannya yaitu $90^{\circ}+90^{\circ}+90^{\circ}=270^{\circ} \mathrm{bu}$.

Pada tahap contemplating, SS menyelesaikan soal PISA berdasarkan konsep matematika yang telah dimiliki serta membuat kesimpulan dengan tepat, memeriksa kembali penyelesaian yang sudah diperoleh serta menyadari dan dapat memperbaiki apabila ada kesalahan, hal ini sesuai dengan yang dikemukakan oleh Suharna (2018) bahwa pada tahap contemplating, siswa menyadari jika terdapat kesalahan dalam menyelesaikan masalah dan dapat memperbaikinya, sehingga SS telah memenuhi tahap berpikir reflektif contemplating.

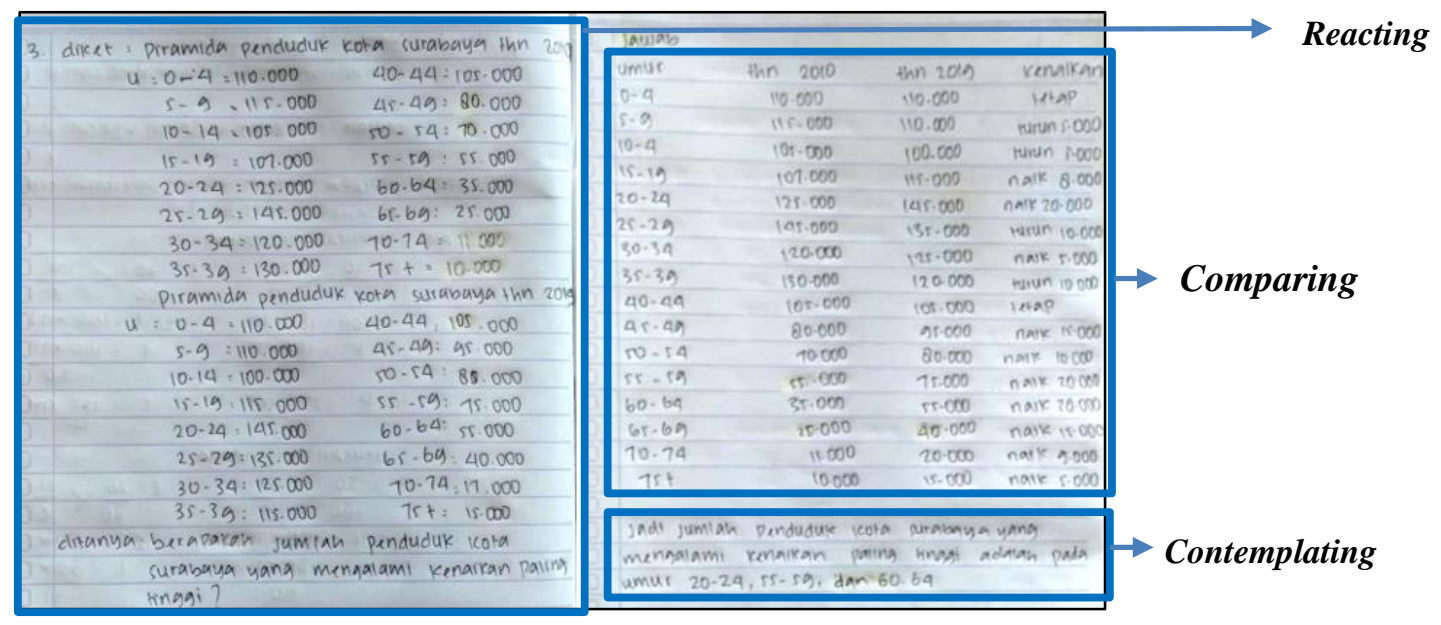

Gambar 4. Hasil Tes Tulis Nomor 2 SS 
Profil Berpikir Reflektif Siswa SMP dalam Menyelesaikan Soal PISA Ditinjau dari Kecemasan Matematika, Linda Kartikasari, Ika Kurniasar

Berdasarkan soal PISA di atas, pada tahap reacting (memahami masalah), SS menuliskan hal yang diketahui dan yang ditanya serta menjelaskan hubungannya, sesuai pernyataan Jannah et al. (2018), siswa menyadari tentang apa yang diketahui dan yang dibutuhkan dengan menyebutkan apa yang diketahui dan yang ditanya. Pada tahap reacting dilakukan wawancara sebagai berikut.

$P: \quad \begin{aligned} & \text { Menurutmu, apakah informasi yang diberikan oleh soal sudah cukup untuk } \\ & \text { menyelesaikan soal tersebut? Coba jelaskan juga alasannya? }\end{aligned}$

SS : Iya, sudah bu. Karena dari gambar kedua piramida pertumbuhan penduduk tersebut saya dapat mencari jumlah penduduk yang mengalami kenaikan paling tinggi bu.

Pada tahap comparing, SS menyusun rencana berdasarkan konsep matematika yang telah dimiliki, menyatakan pernah menjumpai soal yang serupa serta menganalisis metode/strategi yang efektif, sesuai pernyataan Juhaevah (2017), tahap comparing siswa memberikan strategi alternatif dalam menyelesaikan masalah. Pada tahap comparing SS dilakukan wawancara sebagai berikut.

$P \quad$ : Coba jelaskan langkah awal ketika kamu menyelesaikan soal PISA nomor 2? Lalu metode/strategi apa yang kamu anggap efektif dalam menyelesaikan soal PISA tersebut?

SS : $\quad$ Saya membaca dan memahami soal, kemudian menulis yang diketahui dan ditanya serta mengamati gambar kedua piramida pertumbuhan penduduk, lalu menyelesaikannya bu. Metode/strategi yang saya gunakan dengan melihat gambar kedua diagram pertumbuhan penduduk dan menyelesaikan soal tersebut sesuai dengan yang ditanyakan dalam soal.

$P \quad$ : Pernahkah kamu menjumpai soal yang serupa dengan soal tersebut sebelumnya? Coba jelaskan perbedaan dan persamaan antara soal yang sebelumnya sudah pernah kamu jumpai dengan soal PISA yang sudah kamu kerjakan?

SS : $\quad$ Sudah pernah bu, tetapi tidak sama. Persamaannya yaitu sama-sama tentang diagram batang, sedangkan perbedaanya biasanya cuma ada 1 diagram dan tidak tentang kisaran

Pada tahap berpikir reflektif contemplating ketika melaksanakan rencana dan memeriksa kembali pada subjek SR dilakukan wawancara sebagai berikut.

$P \quad: \quad$ Selanjutnya, dengan cara apa kamu menyelesaikan soal PISA nomor 2 tersebut? Jelaskan pula kesimpulan yang kamu peroleh setelah menyelesaikan soal tersebut?

SS : Saya menyelesaikan soal nomor 2 dengan mendata terlebih dahulu kisaran jumlah penduduk tahun 2010 dan 2019 pada setiap umur yang ada dalam diagram kemudian mendata pertumbuhan penduduk pada tahun 2010 dan tahun 2019 apakah mengalami kenaikan, penurunan atau tetap, setelah itu saya dapat menemukan pada umur berapa jumlah penduduk laki-laki yang mengalami kenaikan paling tinggi bu. Kesimpulannya yaitu jumlah penduduk laki-laki yang mengalami kenaikan paling tinggi pada umur 2024 tahun, 55-59 tahun, dan 60-64 tahun yaitu mengalami kenaikan sebanyak 20.000 jiwa.

$P \quad: \quad$ Apakah kamu telah memeriksa ulang penyelesaian yang telah kamu dapatkan? Kemudian jelaskan bagaimana kamu memeriksa kembali penyelesaianmu?

SS : $\quad$ Sudah bu. Dengan melihat kembali data kisaran jumlah penduduk tahun 2010 dan 2019 pada setiap umur serta data kenaikan dari pertumbuhan penduduk yang sudah saya data sebelumnya apakah sudah benar atau belum serta mengamati hasil akhirnya bu. 
Pada tahap contemplating, SS menggunakan konsep matematika yang dimiliki serta membuat kesimpulan dengan tepat, memeriksa kembali penyelesaian yang telah dibuat serta menyadari dan memperbaiki apabila ada kesalahan, sesuai pernyataan Juhaevah (2017), siswa memeriksa seluruh tahapan penyelesaian masalah dari awal hingga akhir serta memastikan bahwa penyelesaian yang diperoleh telah menjawab pertanyaan pada soal, sehingga SS telah memenuhi tahap contemplating.

3. Berpikir reflektif siswa SMP ketika menyelesaikan soal PISA matematika pada tingkat kecemasan matematika tinggi

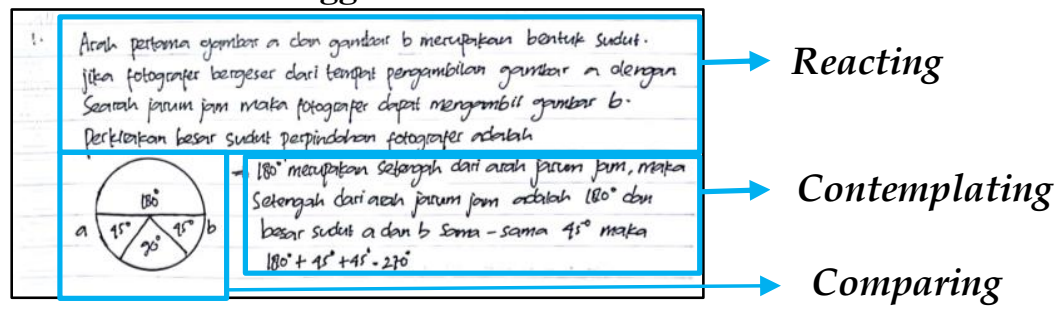

Gambar 5. Hasil Tes Tulis Nomor 1 ST

Berdasarkan tes soal PISA di atas, pada tahap reacting (memahami masalah), ST menuliskan hal yang diketahui dan yang ditanya serta menjelaskan hubungannya, sesuai yang dikemukakan Jannah et al. (2018), siswa menyadari tentang apa yang diketahui dan yang dibutuhkan dengan menyebutkan apa yang diketahui dan yang ditanya. Tahap reacting dilakukan wawancara berikut.

$P$ : Menurutmu, apakah informasi yang diberikan pada soal sudah cukup untuk menyelesaikan soal tersebut? Coba jelaskan juga alasannya?

ST : $\quad$ Iya bu, sudah. Karena setelah menghitung saya dapat menentukan hasil akhirnya yaitu besar sudut perpindahannya pada soal nomor 1 tersebut bu.

Pada tahap comparing, ST menyusun langkah awal berdasarkan konsep matematika yang sudah dimiliki, menyatakan bahwa sebelumnya sudah pernah menjumpai soal yang serupa dengan menganalisis perbedaan dan persamaannya, dan menganalisis metode/strategi yang efektif, sesuai pernyataan Juhaevah (2017), pada tahap comparing siswa dapat memberikan strategi alternatif dalam menyelesaikan masalah. Pada tahap comparing dilakukan wawancara sebagai berikut.

$P$ : Apa langkah awal yang kamu lakukan ketika menyelesaikan soal PISA tersebut? Kemudian metode/strategi apa yang efektif dalam menyelesaikan soal PISA tersebut?

ST : Saya mecoba membaca soal dan mengulang-ngulangi lagi agar bisa lebih faham, kemudian saya mencoba menggambar sudut perpindahannya bu. Metode/strategi yang efektif menggunakan pengetahuan tentang konsep sudut yang pernah saya pelajari dengan menggambar lingkaran kemudian membaginya dalam beberapa besar sudut bu.

$P$ : Apakah kamu pernah menjumpai soal yang serupa dengan soal PISA tersebut? Jika pernah, coba jelaskan perbedaan dan persamaannya?

ST : $\quad$ Iya bu, pernah. Persamaannya yaitu mencari besar sudut. Perbedaannya, pada soal yang pernah saya jumpai sudah diketahui gambar dan besar sudut sebagai bantuan, sedangkan pada soal tes tersebut tidak diberikan besar sudut sebagai bantuan bu 
Profil Berpikir Reflektif Siswa SMP dalam Menyelesaikan Soal PISA Ditinjau dari Kecemasan Matematika, Linda Kartikasari, Ika Kurniasar

Pada tahap berpikir reflektif contemplating ketika melaksanakan rencana dan memeriksa kembali pada subjek SR dilakukan wawancara sebagai berikut.

$P$ : Selanjutnya, dengan cara apa kamu menyelesaikan soal PISA nomor 1? Jelaskan pula kesimpulan yang kamu peroleh setelah menyelesaikan soal PISA tersebut?

ST : $\quad$ Saya menyelesaikan soal dengan cara mencari besar sudut dari gambar a dan b searah jarum jam dengan membuat lingkaran lalu membagi lingkaran tersebut dengan besar sudut yaitu $45^{\circ}, 180^{\circ}$, dan $45^{\circ}$ bu. Kesimpulan yang saya peroleh yaitu besar sudut perpindahan dari gambar a ke gambar b yaitu $45^{\circ}+180^{\circ}+45^{\circ}=270^{\circ}$ bu

$P$ : Apakah kamu telah memeriksa kembali penyelesaian yang kamu dapatkan? Kemudian jelaskan bagaimana kamu memeriksa kembali penyelesaianmu?

ST : $\quad$ Sudah bu. Dengan cara mengamati kembali gambar a dan gambar b kemudian melihat hasil besar sudut perpindahan yang sudah saya hitung yaitu $45^{\circ}+180^{\circ}+45^{\circ}=270^{\circ}$.

Pada tahap contemplating, ST menyelesaikan soal PISA berdasarkan konsep matematika yang dimiliki, membuat kesimpulan dengan tepat, dan memeriksa kembali penyelesaian yang dibuat, sesuai pendapat Mardiyah (2019), pada tahap contemplating siswa melakukan tranformasi terhadap konsep yang sudah mereka miliki untuk membentuk konsep baru dalam menyelesaikan masalah.

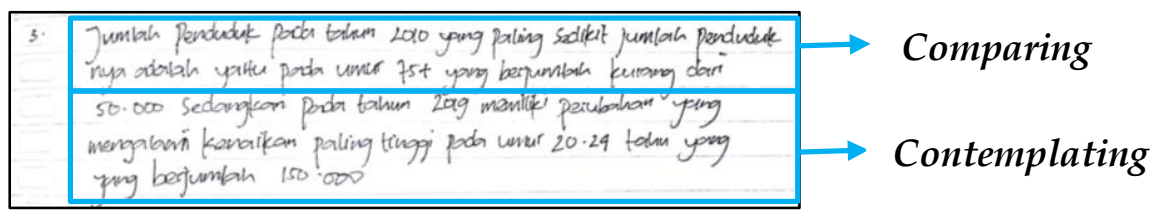

Gambar 6. Hasil Tes Tulis Nomor 2 ST

Hasil tes soal PISA di atas, pada tahap reacting ST tidak menuliskan hal yang diketahui dan yang ditanya, berdasarkan pernyataan Lutfiananda et al. (2016) pada tahap reacting, siswa menyebutkan apa saja yang diketahui dan yang ditanyakan serta hubungan antara hal yang diketahui dan yang ditanya, tetapi ST tidak melakukannya. Pada tahap reacting dilakukan wawancara berikut.

$P \quad$ : Bisa kamu jelaskan hal yang diketahui dan yang ditanya pada soal PISA tersebut? Mengapa kamu tidak menuliskannya pada lembar jawaban?

ST : Yang diketahui adalah diagram pertumbuhan penduduk, dan yang ditanya adalah kenaikan penduduk laki-laki yang paling tinggi. Saya tidak menuliskan yang ditanya dan diketahui karena saya masih bingung dengan soal sehingga saya lupa menuliskannya bu

$P$ : Apakah informasi yang diberikan oleh soal sudah cukup untuk menyelesaikan soal PISA?

ST : $\quad$ Sudah bu, tetapi saya sedikit bingung, karena saya baru pertama kali ini menemukan bentuk diagram seperti itu dan langsung ada 2 diagram, tetapi saya berusaha mencoba menjawabnya sebisa saya dan saya menemukan hasil akhirnya bu.

Pada tahap comparing, ST menyusun rencana berdasarkan konsep matematika yang dimiliki, mengklarifikasi belum pernah menghadapi soal yang serupa, dapat menganalisis metode/strategi yang efektif, sesuai pernyataan Juhaevah (2017) bahwa siswa dapat memberikan strategi alternatif dalam menyelesaikan masalah. Pada tahap comparing ST dilakukan wawancara sebagai berikut. 
$P: \quad \begin{aligned} & \text { Coba jelaskan langkah awal ketika kamu menyelesaikan soal PISA tersebut? Lalu } \\ & \text { pernahkah kamu menjumpai soal yang serupa dengan soal tersebut sebelumnya? }\end{aligned}$
ST : $\begin{aligned} & \text { Saya mecoba memahami soal, kemudian saya mengamati kedua diagramnya bu. Kalau } \\ & \text { yang seperti itu belum pernah, kalau tentang diagram batang sudah pernah, tapi tidak } \\ & \text { sama bu, biasanya diagram batangnya cuma } 1 \text { dan sudah ada jumlah pastinya, } \\ & \text { sedangkan pada soal tersebut jumlahnyanya kisaran atau tidak pasti bu }\end{aligned}$
$P: \quad \begin{aligned} & \text { Metode/strategi apa yang kamu anggap efektif dalam menyelesaikan soal PISA tersebut? } \\ & \text { ST: }\end{aligned}$
$\quad \begin{aligned} & \text { Saya melihat dan mengamati kedua diagram batang tersebut dan saya dapatkan bahwa } \\ & \text { jumlahduduk yang paling rendah pada tahun 2010 pada usia } 75 \text { tahun keatas, setelah }\end{aligned}$
itu saya mencari kenaikan penduduk yang paling tinggi bu.

Pada tahap berpikir reflektif contemplating ketika melaksanakan rencana dan memeriksa kembali pada subjek SR dilakukan wawancara sebagai berikut.

$P \quad$ : Selanjutnya, dengan cara apa kamu menyelesaikan soal PISA nomor 2 tersebut?

ST: Sebenarnya saya masih bingung dengan soal, saya melihat diagram pertumbuhan penduduk tahun 2010-2019 dan menurut saya jumlah penduduk laki-laki yang mengalami kenaikan paling tinggi yaitu pada usia 20-24 tahun yang berjumlah 150.000 jiwa bu

$P \quad: \quad$ Kenapa kamu mengatakan bahwa jumlah penduduk laki-laki yang mengalami kenaikan paling tinggi pada usia 20-24 tahun? Kemudian jelaskan pula kesimpulan yang kamu peroleh setelah menyelesaikan soal PISA tersebut?

ST : $\quad$ Saya menjawab berdasarkan sepengetahuan saya sesudah melihat diagramnya, tetapi saya belum bisa memberikan alasannya karena saya masih sedikit bingung dengan soal bu. Kesimpulan yang saya peroleh yaitu jumlah penduduk laki-laki yang mengalami kenaikan paling tinggi pada usia 20-24 tahun yang berjumlah 150.000 jiwa bu.

$P$ : Bagaimana kamu memeriksa kembali penyelesaian yang telah kamu peroleh? Lalu apakah kamu yakin penyelesaianmu sudah benar?

ST : $\quad$ Dengan cara mengamati kembali langkah penyelesaian yang sudah saya lakukan apakah sudah benar atau ada yang kurang tepat serta melihat hasil akhir yang saya peroleh. Saya belum yakin benar untuk soal nomor 2 bu, karena saya baru pertama kali menjumpai soal seperti itu sehingga saya masih bingung untuk penyelesaiannya.

Pada tahap contemplating, ST menggunakan konsep matematika yang dimiliki serta membuat kesimpulan tetapi tidak disertai penjelasan, memeriksa kembali penyelesaian yang dibuat, menyadari ada kesalahan tetapi belum dapat memperbaiki kesalahan tersebut, berdasarkan pendapat Suharna (2018) pada tahap contemplating siswa mampu menyadari jika terdapat kesalahan dalam menyelesaikan masalah dan dapat memperbaikinya, sedangkan ST tidak melakukannya.

\section{KESIMPULAN}

Berdasarkan hasil penelitian dan pembahasan yang telah didapat, peneliti menyimpulkan pada profil berpikir reflektif siswa SMP dalam menyelesaikan soal PISA ditinjau dari kecemasan matematika yaitu pada tahap reacting ketika memahami masalah, siswa dengan kecemasan matematika rendah menuliskan hal yang diketahui dan yang ditanya serta menjelaskan keterkaitan antara hal yang diketahui dan yang ditanya. Pada tahap comparing ketika menyusun rencana, siswa menyusun langkah awal berdasarkan konsep matematika yang dimiliki, menyatakan sebelumnya pernah menjumpai soal yang 
Profil Berpikir Reflektif Siswa SMP dalam Menyelesaikan Soal PISA Ditinjau dari Kecemasan Matematika, Linda Kartikasari, Ika Kurniasar

serupa dengan menganalisis persamaan dan perbedaannya, serta menganalisis metode/strategi yang efektif. Pada tahap contemplanting ketika melaksanakan rencana dan memeriksa kembali, siswa menyelesaikan soal PISA berdasarkan konsep matematika dan membuat kesimpulan dengan tepat, memeriksa kembali penyelesaian yang dibuat serta menyadari dan memperbaiki apabila ada kesalahan.

Pada tahap reacting ketika memahami masalah, siswa dengan kecemasan matematika sedang menunjukkan bahwa pada soal PISA pertama yaitu soal PISA level 4 dengan konten ruang dan bentuk (space and shape) dan proses menafsirkan (interpret), siswa tidak menuliskan hal yang diketahui dan yang ditanya serta tidak menjelaskan keterkaitan antara hal yang diketahui dan yang ditanya. Pada soal PISA kedua yaitu soal PISA level 4 dengan konten ketidakpastian dan data (uncertainty and data), proses menerapkan (employ), siswa menuliskan hal yang diketahui dan yang ditanya serta menjelaskan hubungan antara hal yang diketahui dan yang ditanya. Pada tahap comparing ketika menyusun rencana, siswa menyusun rencana berdasarkan konsep matematika yang dimiliki, pernah menjumpai soal yang serupa dengan menganalisis perbedaan dan persamaannya serta menganalisis metode/strategi yang efektif. Pada tahap contemplanting ketika melaksanakan rencana dan memeriksa kembali, siswa menyelesaikan soal PISA berdasarkan konsep matematika serta membuat kesimpulan dengan tepat, memeriksa kembali penyelesaian yang dibuat serta menyadari dan memperbaiki apabila ada kesalahan.

Pada tahap reacting ketika memahami masalah, siswa dengan kecemasan matematika tinggi menunjukkan pada soal PISA pertama yaitu soal PISA level 4, konten ruang dan bentuk (space and shape) dan proses menafsirkan (interpret), siswa menuliskan hal yang diketahui dan yang ditanya serta menjelaskan hubungannya, tetapi pada soal PISA kedua yaitu soal PISA level 4, konten ketidakpastian dan data (uncertainty and data), dan proses menerapkan (employ), siswa tidak menuliskan dan menjelaskan hubungan antara hal yang diketahui dan yang ditanya. Pada tahap comparing (menyusun rencana), siswa menyusun langkah awal berdasarkan konsep matematika, menyatakan pernah menjumpai soal yang serupa dengan menganalisis persamaan dan perbedaannya, dan menganalisis metode/strategi yang efektif. Pada tahap contemplanting ketika melaksanakan rencana dan memeriksa kembali, siswa menyelesaikan soal PISA berdasarkan konsep matematika, membuat kesimpulan dengan tepat, memeriksa ulang penyelesaian yang telah dibuat serta menyadari ada kesalahan pada penyelesaian soal PISA yang kedua tetapi belum dapat memperbaiki kesalahan tersebut. Berdasarkan tiga tingkat kecemasan matematika di atas maka peneliti menyimpulkan bahwa siswa dengan tingkat kecemasan matematika rendah melakukan reacting, comparing, dan contemplating pada tahap memahami masalah, menyusun rencana, melaksanakan rencana, dan memeriksa kembali dalam menyelesaikan soal PISA, sedangkan siswa dengan kecemasan matematika sedang tidak melakukan reacting pada tahap memahami masalah dan siswa dengan kecemasan matematika tinggi tidak melakukan reacting dan contemplating pada tahap memahami masalah dan memeriksa kembali.

Siswa mempunyai perbedaan pada kemampuan berpikir reflektif dan tingkat kecemasan matematika pada setiap individu ketika menyelesaikan soal PISA. Oleh karena itu untuk meningkatkan kemampuan berpikir reflektif siswa dalam menyelesaikan soal PISA matematika diharapkan guru dapat 
mengembangkan kegiatan belajar mengajar yang melibatkan soal berstandar PISA. Setelah mengetahui kemampuan berpikir reflektif siswa, diharapkan siswa mampu meningkatkan kemampuan mereka dalam menyelesaikan permasalahan matematika disertai dengan argumentasi yang sesuai dan tepat.

\section{REFERENSI}

Al Mutawah, M. A. (2015). The Influence of Mathematics Anxiety in Middle and High School Students $\begin{array}{lllll}\text { Math Achievement. International Education Studies, } & \text { 8(11), } 239 .\end{array}$ https://doi.org/https://doi.org/10.5539/ies.v8n11p239

Ariestyan, Y., Sunardi, \& Kurniati, D. (2016). Proses Berpikir Reflektif Siswa Dalam Menyelesaikan Soal Matematika Materi Sistem Persamaan Linear Dua Variabel. 28(2), 250-250. https://doi.org/https://doi.org/10.4234/jjoffamilysociology.28.250

Fuady, A. (2017). Berpikir Reflektif Dalam Pembelajaran Matematika. JIPMat, I(2). https://doi.org/https://doi.org/10.26877/jipmat.v1i2.1236

Jannah, M., Widadah, S., \& Fachrudin, A. D. (2018). Profil berpikir reflektif siswa sma dalam memecahkan masalah matematika ditinjau dari kemampuan matematika. 1-7.

Juhaevah, F. (2017). Profil Kemampuan Berpikir Reflektif Siswa Smp Dalam Memecahkan Masalah Matematika Standar Pisa Ditinjau Dari Perbedaan Gender. https://doi.org/https://doi.org/10.33477/mp.v5i2.770

Kusumaningrum, M., \& Saefudin, A. A. (2012). Mengoptimalkan Kemampuan Berpikir Matematika melalui Pemecahan Masalah Matematika. Prosiding Kontribusi Pendidikan Matematika Dan Matematika Dalam Membangun Karakter Guru Dan Siswa, November, 978-979.

Lutfiananda, I. M. A., Mardiyana, \& Saputro, D. R. S. (2016). Analisis Proses Berpikir Reflektif Siswa Dalam Memecahkan Masalah Matematika Non Rutin Di Kelas VIII Smp Islamic International School Pesantren Sabilil Muttaqien (IIS PSM) Magetan Ditinjau Dari Kemampuan Awal. Jurnal Elektronik Pembelajaran Matematika, 4(9), 812-823.

Machromah, I. U., Riyadi, \& Usodo, B. (2015). Analisis Proses Dan Tingkat Berpikir Kreatif. Jurnal Elektronik Pembelajaran Matematika, 3(6), 613-624.

Mardiyah, U. R. (2019). Abstraksi Reflektif dalam Mengontruk Bangun Segiempat. 8(2), 517-523.

Melisa. (2019). Pengaruh Kecemasan Matematika terhadap Kemampuan Pemecahan Masalah Matematis berdasarkan Gender.

Miles, M. B., Huberman, A. M., \& Saldana, J. (2014). Qualitative data analysis: A methods sourcebook. Sage.

Mutodi, P., \& Ngirande, H. (2014). Exploring mathematics anxiety: Mathematics students' experiences. Mediterranean Journal of Social Sciences, 5(1), 283-294. https://doi.org/https://doi.org/10.5901/mjss.2014.v5n1p283

Nursalam. (2013). Metodologi Penelitian Ilmu Keperawatan, Edisi 3 (3rd ed.). Salemba Medika.

Odafe, V. U. (2008). Teaching and Learning Mathematics: Student Reective Adds a New Dimension. 
Profil Berpikir Reflektif Siswa SMP dalam Menyelesaikan Soal PISA Ditinjau dari Kecemasan Matematika, Linda Kartikasari, Ika Kurniasar

Proceedings of the Ninth International Conference: Mathematics Education in a Global Community, 486-490.

OECD. (2013). PISA 2012 Assesssment and Analytical Framework Mathematics, Reading, Science, Problem Solving, And Financial Literacy. In Echinoderms: Durham - Proceedings of the 12th International Echinoderm Conference. OECD.

OECD. (2016). Pisa 2015 Results in Focus. In Pisa 2015.

OECD. (2018). PISA 2018 Assessment and Analytical Framework. OECD.

OECD. (2019). PISA 2018 Assessment and Analytical Framework. In OECD Publishing. OECD.

Puspitasari, F. (2019). Analisis Proses Berpikir Reflektif Siswa dalam Menyelesaikan Soal Matematika Bertipe HOTS Ditinjau dari Adversity Quotient.

Putra, Y. Y., \& Vebrian, R. (2020). Literasi Matematika (Mathematical Literacy). Deepublish.

Rasyid, M. A., Budiarto, M. T., \& Lukito, A. (2017). Profil Berpikir Reflektif Siswa SMP dalam Pemecahan Masalah Pecahan Ditinjau dari Perbedaan Gender. Kreano, Jurnal Matematika Kreatif-Inovatif, 8(2), 171-181. https://doi.org/https://doi.org/10.15294/kreano.v8i2.9849

Rhaudyatun, A. (2017). Pengaruh Metode Cornell Note-Taking Terhadap Kemampuan Berpikir Reflektif Matematis Siswa.

Roebyanto, G., \& Harmini, S. (2017). Pemecahan Masalah Matematika untuk PGSD. Remaja Rosdakarya.

Ruseffendi, E. T. (2006). Pengantar kepada Membantu Guru Mengembangkan Kompetensinya dalam Pengajaran Matematika untuk Meningkatkan CBSA. Tarsito.

Suhaji, I. P., Widadah, S., \& Sukriyah, D. (2020). Kemampuan Berpikir Reflektif Dalam Memecahkan Masalah Matematika Ditinjau Dari Gaya Kognitif. 5(1). https://doi.org/https://doi.org/10.31102/zeta.2020.5.1.8-15

Suharna, H. (2018). Teori Berpikir Reflektif dalam Menyelesaikan Masalah Matematika. Deepublish.

Supriatna, A., \& Zulkarnaen, R. (2019). Studi Kasus Tingkat Kecemasan Matematis Siswa SMA. 730735 .

Walle, J. A. Van De. (2008). Sekolah Dasar dan Menengah Matematika Pengembangan Pengajaran. Erlangga.

Wiryanto. (2014). Level-Level Abstraksi dalam Pemecahan Masalah Matematika. 569-578. 